\title{
Effect of dairy by-products as milk replacers on quality attributes of ice cream
}

\author{
R. B. Meneses, ${ }^{1} \oplus$ M. S. Silva, ${ }^{1} \odot$ M. L. G. Monteiro, ${ }^{2,3,4}{ }^{\oplus}$ M. H. M. Rocha-Leão, ${ }^{5}$ and C. A. Conte-Junior ${ }^{2,3,4 *}$ (]) \\ ${ }^{1}$ Department of Food, Federal Institute of Education, Science and Technology of Alagoas (IFAL), 57120-000, Maceió, Brazil \\ ${ }^{2}$ Institute of Chemistry, Federal University of Rio de Janeiro (UFRJ), 21949-900, Rio de Janeiro, Brazil \\ ${ }^{3}$ Center for Food Analysis (NAL-LADETEC), Federal University of Rio de Janeiro (UFRJ), 21941-598, Rio de Janeiro, Brazil \\ ${ }^{4}$ Department of Food Technology, Fluminense Federal University (UFF), 24220-000, Rio de Janeiro, Brazil \\ ${ }^{5}$ School of Chemistry, Federal University of Rio de Janeiro (UFRJ), 21949-900, Rio de Janeiro, Brazil
}

\section{ABSTRACT}

The aim of this study was to evaluate the effect of ricotta whey $(\mathrm{RW})$, cheese whey $(\mathrm{CW})$, and butter whey (BUW) as replacers of whole milk (WM) at different ratios $(0: 100,25: 75,50: 50,75: 25$, and 100:0) in the physicochemical and sensory qualities of ice cream. All formulations, including a commercial sample used as reference, were analyzed for nutritional composition, energy value, $\mathrm{pH}$, titratable acidity (TA), melting behavior, desorption index, instrumental color properties, instrumental hardness, and consumer sensory testing. Overall, the addition of RW, CW, and BUW increased the moisture content, TA, melting rate, and redness $\left(a^{*}\right)$ and yellowness $\left(b^{*}\right)$ values but decreased the $\mathrm{pH}$, lightness $\left(L^{*}\right)$ value, energy value, levels of ash, protein, lipid, and carbohydrate. As exception, CW did not influence the TA, and BUW resulted in lower lipid reduction and in lower hardness changes, and it did not affect the content of ash, protein, and $a^{*}$ and $b^{*}$ values of ice creams. Any ice cream formulation had dietary fibers and a desorption index. Ricotta whey and CW at all ratios and BUW at $25 \%$ did not affect overall liking compared with the commercial sample, whereas purchase intention was only decreased by the addition of BUW from 50 to $100 \%$. Ricotta whey at 75 and $100 \%$ decreased melting velocity and creaminess, and BUW at 50, 75, and $100 \%$ increased hardness, TA, and cream flavor but decreased creaminess, which contributed negatively to overall liking. Therefore, the evaluated dairy by-products, especially RW and CW, have great potential for replacing milk in ice creams.

Key words: ricotta whey, cheese whey, butter whey, physicochemical quality, sensory evaluation

Received February 7, 2020.

Accepted June 22, 2020

*Corresponding author: conte@iq.ufrj.br

\section{INTRODUCTION}

Ice cream is one of the most popular and consumed desserts in the world, and its main ingredient is cow's milk, which contains a wide variety of high-quality nutrients for human health, such as protein, vitamins, and minerals; however, milk lipids have been associated with an increase of cholesterol levels in the blood (FAO, 2013; Agrawal, 2016). Simultaneously, the dairy industry has been paying attention to dairy by-products such as wheys from the production of cheese, ricotta, and butter. These by-products represent approximately $80 \%$ of the total milk used for dairy product processing and therefore, generate high disposal costs (Panesar and Kennedy, 2012; FAO, 2013).

Dairy wheys from the processing of cheeses, ricotta, and butter have bioactive substances for human health, are low fat, and have good functional and technological properties, representing a low-cost raw material for milk replacement in traditional dairy products (Morin et al., 2006; Bald et al., 2014; Cortellino and Rizzolo, 2018). Several studies have evaluated milk replacement by whole cheese whey (CW; Sakhale et al., 2012; Castro et al., 2013), ricotta whey (RW; Gerhardt et al., 2013; Cortellino and Rizzolo, 2018), and butter whey (BUW; Hickey et al., 2018) in several dairy products. However, there are no reports regarding RW and BUW used as milk replacers in ice cream. Cheese whey was studied only by Haque and Ji (2003) and Rodríguez and M'Boumba (2011); however, the whey evaluated by these authors was from cheddar cheese.

The use of dairy whey in ice cream will affect physicochemical characteristics leading to changes in qualities such as nutritional composition, color, aroma, flavor (sweetness), creaminess, and melting behavior, which are essential factors for consumer acceptance (Castro et al., 2013; Hickey et al., 2018) and are the main challenge for use of whey in conventional dairy products at industrial scale. Overall, the adverse quality effects are mainly associated with type of dairy whey, ingredient ratios, and processing conditions of ice cream (Haque and Ji, 2003; Morin et al., 2006; Bald et 
al., 2014; Agrawal, 2016; Cortellino and Rizzolo, 2018). Therefore, the changes on physicochemical and sensory qualities of ice cream made with rennet cheese, ricotta, and butter wheys are still unknown. In this context, the aim of this study was to investigate the effects of adding these types of dairy whey on the physicochemical and sensory characteristics of cream ice cream.

\section{MATERIALS AND METHODS}

\section{Dairy By-Product Samples}

Ricotta whey, CW, and BUW from ricotta, rennet cheese, and butter production, respectively, were obtained in an agro-industry plant located at Federal Institute of Alagoas, Brazil. Five liters of each dairy whey were distributed in 1-L plastic bottles, frozen at $-18^{\circ} \mathrm{C}$, and transported to the laboratory in polystyrene boxes containing ice. The transportation time did not exceed $12 \mathrm{~h}$.

\section{Ice Cream Production}

All ice cream formulations developed in this study are exhibited in Table 1. Whole milk (WM) and each dairy by-product (RW, CW, and BUW) were combined at different ratios $(0: 100,25: 75,50: 50,75: 25$, and 100:0, $\mathrm{wt} / \mathrm{wt}$ ). All dairy wheys were thawed overnight at $10 \pm$ $1^{\circ} \mathrm{C}$ before use in ice cream formulations. The other ingredients (Table 1) were purchased from a local market in Rio de Janeiro, Brazil. The cream flavor was chosen because it may mask undesirable characteristics due to use of dairy wheys.

The ice creams were produced through homogenization of all ingredients followed by pasteurization $\left(80^{\circ} \mathrm{C}\right.$ for $30 \mathrm{~s})$, maturation $\left(4^{\circ} \mathrm{C}\right.$ for $\left.12 \mathrm{~h}\right)$, and a final step in the ice cream maker (Cuisinart ICE-100, Stamford, $\mathrm{CT})$ to reach an adequate consistency (30-40 $\mathrm{min})$. Then, ice creams were placed in plastic cups $(30 \mathrm{~mL})$ and stored at $-18^{\circ} \mathrm{C}$ until further analysis. In addition, a commercial brand with a high market share (Kibon, Rio de Janeiro, Brazil) of cream ice cream was analyzed as a reference sample to compare the physicochemical and sensory qualities between ice cream formulations made with dairy wheys and a commercial ice cream well accepted by consumers.

\section{Bacteriological Analysis}

Bacteriological analysis included Staphylococcus aureus, thermotolerant coliforms at $45^{\circ} \mathrm{C}$, and Salmonella spp. (APHA, 2001). These analyses were carried out to evaluate the processing conditions such as heat treatment and hygienic practices during preparation of ice creams ensuring safe final products based on standard limits of national and international agencies (WHO, 1983; ANVISA, 2001).

\section{Determination of the Nutritional Composition}

The contents of moisture, ash, protein and dietary fiber were determined according to AOAC International methods (AOAC International, 2012). The total lipid content was determined through cold-extraction (Bligh and Dyer, 1959). The total carbohydrate amount was calculated by the difference between $100 \%$ and the sum of the moisture, ash, protein and lipid contents, whereas the energy value was determined based on the Atwater coefficient $(4 \mathrm{kcal} / \mathrm{g}, 9 \mathrm{kcal} / \mathrm{g}$, and $4 \mathrm{kcal} / \mathrm{g}$ ) of proteins, lipids, and carbohydrates, respectively (AOAC International, 2012).

\section{Determination of the $\mathrm{pH}$ and Titratable Acidity}

The $\mathrm{pH}$ was directly measured using a digital $\mathrm{pH}$ meter (model DM-23 Digimed, Digicrom Analítica Ltda., São Paulo, Brazil) previously calibrated with $\mathrm{pH} 4.0$ and 7.0 buffer solutions. The titratable acidity (TA) was measured by titration with $0.1 \mathrm{~N} \mathrm{NaOH}$ and results were expressed as percent lactic acid (AOAC International, 2012).

\section{Evaluation of the Melting Behavior}

The analysis of the melting behavior of the ice creams followed the method described by Mahdian et

Table 1. Cream ice cream formulations made with whole milk (WM) and ricotta whey (RW), cheese whey (CW), or butter whey (BUW) at different ratios

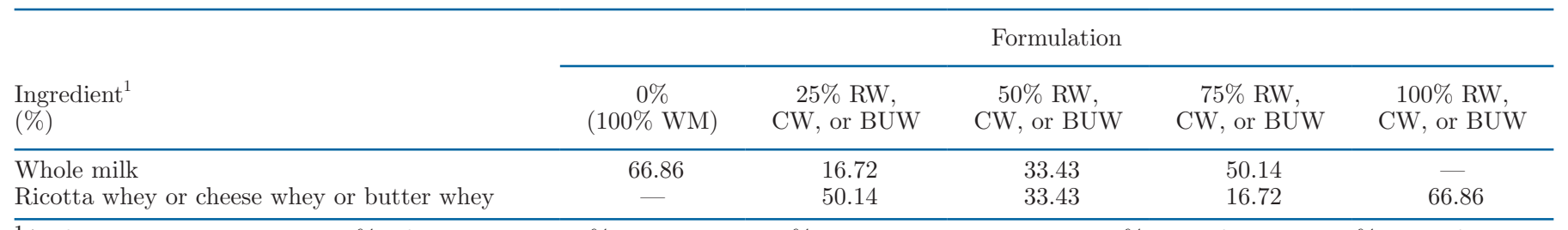

\footnotetext{
${ }^{1}$ All formulations included $17.44 \%$ refined sugar, $11.63 \%$ cream milk, $0.58 \%$ thickener and stabilizer, $0.58 \%$ emulsifier, and $2.91 \%$ cream flavoring.
} 
al. (2012) with some modifications. The frozen samples were carefully removed from plastic cups, and placed in wire mesh $\left(1 \mathrm{~cm}^{2}\right)$ at a controlled temperature $(25 \pm$ $1^{\circ} \mathrm{C}$ ). The melted ice cream was collected with a funnel coupled to a graduated cylinder, which were previously weighed and placed under the wire mesh. The time (min) for the beginning of melting was taken out, and the dropping weight was measured every $5 \mathrm{~min}$ for $1 \mathrm{~h}$. Then, a graph was constructed by plotting the melted ice cream weights $(\mathrm{g})$ against the times, and results were expressed as melting rate $(\mathrm{g} / \mathrm{min})$.

\section{Determination of the Desorption Index}

Thawed ice creams were observed to verify desorption, according to the methodology of Cheng et al. (2015) with some modifications. The graduated cylinder with melted ice cream was slightly sealed, stored and observed at a controlled temperature $\left(25 \pm 1^{\circ} \mathrm{C}\right)$ for $1 \mathrm{~h}$. If applicable (presence of phase separation), the volume of the serum fraction formed in each sample was registered, and the desorption index (DI) was determined by the following equation: DI $(\%)=\left(\mathrm{H}_{\text {serum fraction }} /\right.$ $\left.\mathrm{H}_{\text {melted ice cream }}\right) \times 100$, where $\mathrm{H}_{\text {serum fraction }}=$ volume of the whey layer formed $(\mathrm{mL})$, and $\mathrm{H}_{\text {melted ice cream }}=$ total volume of the melted ice cream $(\mathrm{mL})$.

\section{Instrumental Color Measurements}

Lightness $\left(L^{*}\right)$, redness $\left(a^{*}\right)$, and yellowness $\left(b^{*}\right)$ of the frozen samples were recorded at illuminant D65 and $2^{\circ}$ standard observer using a Konica Minolta CR-400 colorimeter (Konica Minolta Sensing, Osaka, Japan), which was previously calibrated with a white reference plate (AMSA, 2012). This analysis was performed on the samples in plastic cups $(30 \mathrm{~mL})$, immediately after removing the ice creams from freezer.

\section{Instrumental Hardness Measurements}

Each ice cream sample was removed from the freezer $\left(-18^{\circ} \mathrm{C}\right)$ and immediately placed in a polystyrene platform to inhibit the temperature loss during the analysis. Each sample was placed in the center of the metal base of the equipment, and the hardness (peak force during penetration) was measured at controlled temperature $\left(18 \pm 2^{\circ} \mathrm{C}\right)$. The apparatus used was a TA.XT Express texture analyzer (Stable Micro System, Surrey, UK) equipped with a $10-\mathrm{kg}$ load cell, angle of $45^{\circ}$, and $\mathrm{P} / 6$ stainless steel cylindrical probe with nontruncated tip. The test conditions were similar to El-Nagar et al. (2002): constant speed of $1 \mathrm{~mm} / \mathrm{s}$ (pretest, test, and posttest), distance of $25 \mathrm{~mm}$, and force of $0.1 \mathrm{~N}$.

\section{Sensory Analysis}

The Research Ethics Committee of Clementino Fraga Filho University Hospital approved this study (protocol number 77418117.7.0000.5257, Rio de Janeiro, Brazil). In addition, all participants signed an informed consent form before sensory analysis.

Participants. The sociodemographic characteristics of the participants are exhibited in Table 2. Consumers ( $\mathrm{n}=300 ; 133$ men, 164 women, and 3 other gender, ranging from 18-65 years old) were randomly recruited among workers, visitors, and students at Federal University of Rio de Janeiro (Rio de Janeiro, Brazil), according to their interest and availability to participate in the study. The majority of the participants $(\mathrm{n}=204)$ were frequent consumers of ice cream.

Consumer Testing. The sensory evaluation was divided in 3 different trials, one for each evaluated dairy whey according to formulations described in Table 1: formulations at different ratios of (1) RW to WM, (2) $\mathrm{CW}$ to WM, and (3) BUW to WM. In each trial, ice cream formulations, including the commercial brand sample, were served in plastic cups $(30 \mathrm{~mL})$ coded with

Table 2. Sociodemographic characteristics of the participants $(\mathrm{n}=$ 300)

\begin{tabular}{|c|c|}
\hline Characteristic & Value $(\%)$ \\
\hline \multicolumn{2}{|l|}{ Gender } \\
\hline Female & 55 \\
\hline Male & 44 \\
\hline Other & 1 \\
\hline \multicolumn{2}{|l|}{ Age (yr) } \\
\hline $18-25$ & 77 \\
\hline $26-35$ & 18 \\
\hline $36-45$ & 3 \\
\hline $46-55$ & 1 \\
\hline $56-65$ & 1 \\
\hline 66 and older & 0 \\
\hline \multicolumn{2}{|l|}{ Education } \\
\hline Incomplete high school & 1 \\
\hline Complete high school & 1 \\
\hline Incomplete undergraduate & 0 \\
\hline Complete undergraduate & 4 \\
\hline Incomplete graduate & 71 \\
\hline Complete graduate & 4 \\
\hline Postgraduate & 19 \\
\hline \multicolumn{2}{|l|}{ Household income $^{1}$} \\
\hline $1-5$ & 36 \\
\hline$>5-10$ & 37 \\
\hline$>10-20$ & 18 \\
\hline$>20-30$ & 6 \\
\hline$>30$ & 3 \\
\hline \multicolumn{2}{|c|}{ Ice cream consumption frequency } \\
\hline Never & 0 \\
\hline Rarely & 31 \\
\hline Frequently & 68 \\
\hline Daily & 1 \\
\hline More than once a day & 0 \\
\hline
\end{tabular}

${ }^{1}$ Household income was based on Brazilian monthly minimum wage (approximately $\$ 250$ in January 2020). 
a random 3-digit number. Individual ice cream samples were promptly removed from freezer and presented individually to each participant $(\mathrm{n}=100$ for each trial) in isolated booths following the balanced presentation order. Unsalted crackers and water at room temperature were also served to clean the palate between samples.

The acceptance degrees for appearance, aroma, flavor, texture, and overall liking of the ice creams were rated by the participants in a 7-point category hedonic scale $(7=$ like very much; $4=$ neither like nor dislike; $1=$ dislike very much; Stone and Sidel, 2004). The purchase intention was indicated through a 5-point category hedonic scale $(5=$ certainly would buy; $3=$ I might buy it/I might not buy it; 1 = certainly would not buy; Stone and Sidel, 2004). In addition, cream color, cream aroma, cream flavor, sweetness, creaminess, and melting velocity were rated in a 7 -point justabout-right (JAR) scale ( $1=$ extremely little; $5=$ just about right; $7=$ extremely much) to verify attribute intensity ratings by the addition of different proportions of RW, CW, and BUW in ice creams (Palazzo and Bolini, 2017).

\section{Statistical Analysis}

The physicochemical results were obtained from triplicate for each treatment $(\mathrm{n}=3)$. One-way ANOVA followed by Tukey test $(P<0.05)$ was used to compare the mean values of the physicochemical parameters, hedonic scores and JAR scores between the ice cream formulations within the same dairy by-product (RW, CW or BUW). The parameters influenced by addition of each dairy by-product in the ice cream were identified through principal component analysis (PCA), whereas the partial least squares regression (PLSR) detected the positive and negative attributes contributing to overall liking of the ice creams. The attributes in the PLSR were considered relevant to overall liking when respective variable importance in the projection was greater than 1.0 (Wold et al., 2001). The demographic data were evaluated by the frequency of each response. All statistical analyses were carried out using XLSTAT version 2012.6.08 (Addinsoft, New York, NY) software at $95 \%$ of confidence level.

\section{RESULTS AND DISCUSSION}

\section{Bacteriological Evaluation}

All ice cream formulations were suitable for consumption in accordance with the microbiological standard limits recommended by national and international agencies (WHO, 1983; ANVISA, 2001) indicating that processing conditions (i.e., heat treatment and hygienic practices) adopted during the elaboration of ice cream formulations made with dairy whey resulted in safe final products. Similar results were observed in ice creams with whey added to replace milk (Pereira et al., 2014; Tsuchiya et al., 2017).

\section{Nutritional Composition}

The results of proximate composition and energy value are exhibited in Table 3. Overall, addition of RW, CW, and BUW increased the moisture content, whereas they decreased the levels of ash, protein, lipid, carbohydrate, and energy value; however, the decrease of lipid content and energy value was less pronounced in BUW ice creams, and the addition of BUW did not affect the ash and protein levels (Table 3). Our findings for nutritional composition and energy value may be attributed to the compositions of the dairy wheys, which are directly related to technological processing of their correspondent dairy product (Meneses et al., 2020).

No effect of the addition of BUW in the ash and protein contents may be attributed to the fact that butter is obtained by the extraction of the lipid fraction from milk and not by the precipitation or coagulation of milk proteins as in cheese and ricotta (Morin et al., 2006; Walstra et al., 2006). There are no studies in the literature about total or partial replacement of milk by ricotta, rennet cheese, and butter wheys in ice cream. Therefore, our results were also compared with other dairy products. Similar to our findings, Rodrigues et al. (2006) reported a decrease in the protein content replacing milk by $100 \%$ with whey protein-based products (Dairy Pro) in ice creams. Moreover, higher moisture content and lower carbohydrate, lipid, protein, and ash levels were observed in dairy beverages with $\mathrm{CW}$ replacing milk at 60, 80, and 90\% (Carli et al., 2015).

It is worth mentioning that the major change occurred in the lipid content, wherein 75 and $100 \%$ RW, and 50, 75, and $100 \% \mathrm{CW}$ reduced the lipid level by more than $25 \%$ compared with $100 \%$ WM; therefore, they were classified as light according to standards from International Dairy Food Association. When compared with commercial ice cream, the reduction observed for lipid content was more significant, at 34.97 (50\% RW), 50.69 (100\% RW), 32.42 (25\% CW), 54.81 (100\% CW), 28.49 (50\% BUW), and $37.33 \%$ (100\% BUW). These results are extremely promising for the production of low-fat foods for human health. In partial agreement with our results, Prindiville et al. (2000) and Rodrigues et al. (2006) reported a reduction of 41.01 and $68.18 \%$ in the lipid content of ice creams with milk replaced 
Meneses et al.: ICE CREAM MADE WITH MILK REPLACED BY WHEYS

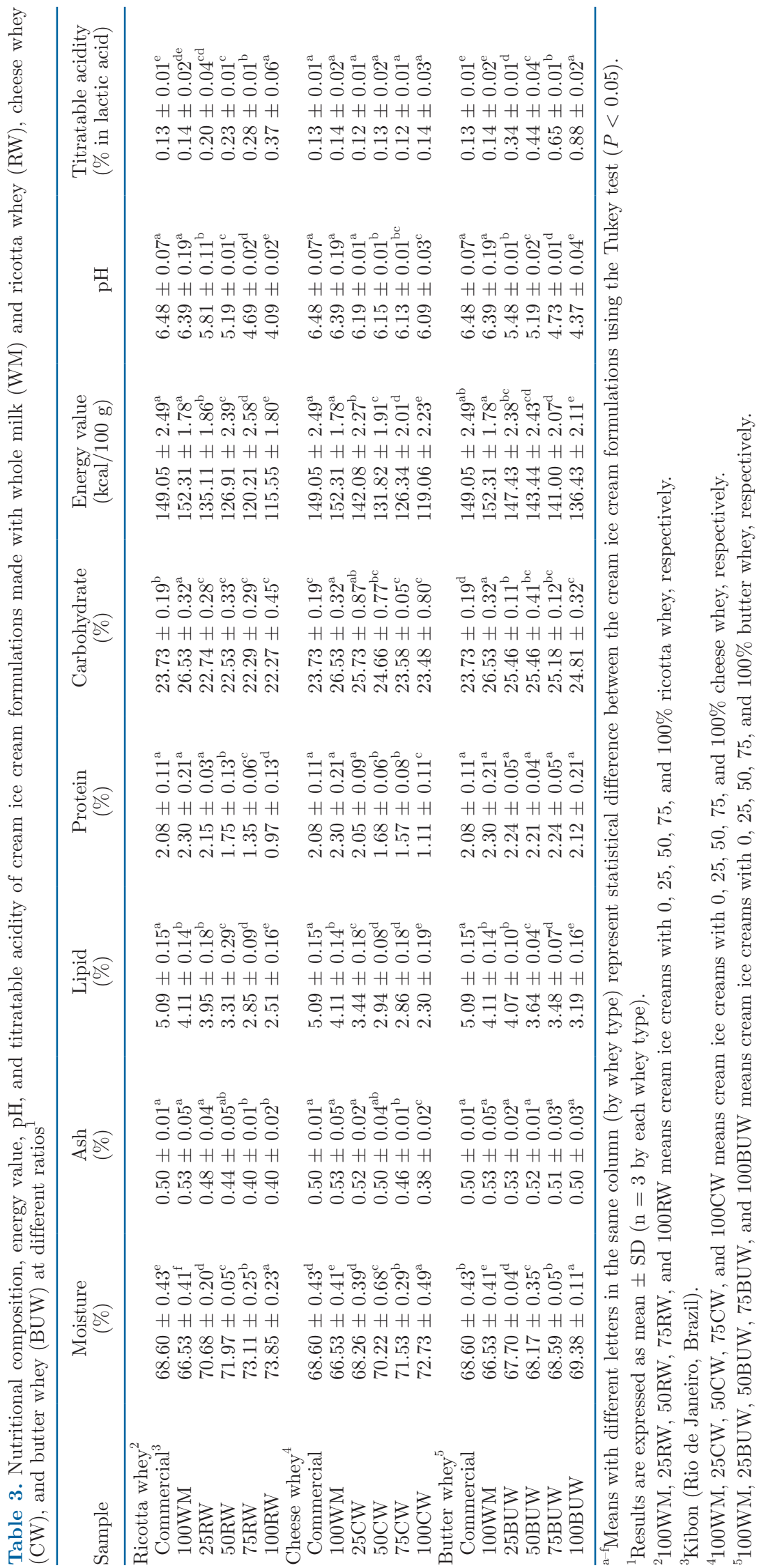


$100 \%$ by whey protein-based products (Dairy Pro, Simplesse, and Dairy-Lo), respectively.

Dietary fibers were not detected in any ice cream formulations due to absence of fibers in WM, RW, CW, BUW, and the other ingredients used in ice cream formulations (Meneses et al., 2020). Similarly, Oliveira et al. (2008) reported no dietary fibers in different types and flavors of commercial ice creams such as cream, light cream, lemon, banana soy, and yogurt.

\section{pH and Titratable Acidity}

For RW ice creams, a decrease $(P<0.05)$ in $\mathrm{pH}$ was observed as the level of RW increased, whereas TA increased $(P<0.05)$ by increasing the RW level from 50 to $100 \%$ (Table 3 ). No difference was observed in TA between $100 \% \mathrm{WM}$ and $25 \%$ RW or 25 and $50 \%$ RW.

With regards to CW, 50, 75, and $100 \%$ CW presented lower $(P<0.05) \mathrm{pH}$ than $25 \% \mathrm{CW}, 100 \% \mathrm{WM}$, and the commercial sample. In addition, $100 \% \mathrm{CW}$ demonstrated lower $(P<0.05) \mathrm{pH}$ than $50 \% \mathrm{CW}$; however, no difference was found between 50 and $75 \% \mathrm{CW}$ or between 75 and $100 \% \mathrm{CW}$ for this parameter. TA was similar in all ice cream formulations.

For BUW ice creams, a decrease $(P<0.05)$ in $\mathrm{pH}$ and an increase $(P<0.05)$ in TA was observed by increasing of BUW level. No difference was observed in $\mathrm{pH}$ and TA between 100\% WM and commercial sample.

In the present study, the commercial sample and $100 \% \mathrm{WM}$ demonstrated $\mathrm{pH}$ and TA ranging from 6.39 to 6.48 and 0.13 to 0.14 , respectively, which is in agreement with previous findings reported for ice creams in the literature (Haque and Ji, 2003; Rodríguez and M'Boumba, 2011).

Variations on $\mathrm{pH}$ and TA of developed ice creams in this study may be due to physicochemical proprieties of each RW, CW, and BUW in relation to WM. Ricotta whey and BUW have lower $\mathrm{pH}$ and higher TA than $\mathrm{WM}$, whereas $\mathrm{CW}$ has lower $\mathrm{pH}$ and similar TA compared with WM, which presents $\mathrm{pH}$ close to neutrality (6.62) and TA of approximately $0.19 \%$ (Meneses et al., 2020). Among the evaluated dairy wheys, bovine CW has approximately $6.36 \mathrm{pH}$ and $0.21 \%$ of TA, which is closer to WM compared with $\mathrm{pH}$ values (4.41 and $4.86)$ and TA $(0.52 \%$ and $0.39 \%)$ of RW and BUW, respectively (Meneses et al., 2020). This fact explains the lower variation in the $\mathrm{pH}$ and $\mathrm{TA}$ of the ice creams with the addition of CW compared with RW and BUW. Haque and Ji (2003) and Rodríguez and M'Boumba (2011), using cheddar cheese whey as milk replacers in ice cream, presented similar results compared with the present study.

\section{Melting Behavior}

An ideal ice cream should have moderate resistance to melting into liquid form when exposed to room temperature for a certain time (Bodyfelt et al., 1988). The time for beginning of melting was 5 min for all ice cream formulations. Commercial ice cream had the highest $(P<0.05)$ melting rate (Table 4$)$.

With regards to RW, an increase of the RW level decreased $(P<0.05)$ the melting rate; however, no difference was found for this parameter between 75 and $100 \%$ RW. For CW ice creams, 50, 75, and $100 \%$ CW had lower $(P<0.05)$ melting rate than $100 \% \mathrm{WM}$ and $25 \% \mathrm{CW}$, which had similar values. No difference was also observed among 50, 75, and 100\% CW. Regarding BUW, 25\% BUW presented a lower $(P<0.05)$ melting rate than $100 \% \mathrm{WM}$; however, no difference was found for this parameter between ice creams produced with BUW (25 and $50 \%$ BUW or 50 and $100 \%$ BUW).

Fat plays a significant role in determining the melting rate of ice cream and is responsible for increasing the resistance to this phenomenon, because part of the globules surrounding the air bubbles stabilize the system (Bodyfelt et al., 1988; Guinard, et al., 1997). Nevertheless, even with lower lipid contents, it was observed that the different dairy wheys increased the resistance to melting of the ice creams, revealing an interesting application of these residues in this dessert. A hypothesis is that more time is required to melting when the ice cream contain more water, which has a higher melting point than milk fat (Choi and Shin, 2014). Another explanation is related to water-holding capacity, which is different depending on $\mathrm{pH}$. The decrease in $\mathrm{pH}$ values lead to protein denaturation and, consequently, binding between whey-whey proteins or whey proteins and caseins, increasing the exposure of hydrophilic groups to aqueous medium, which results in higher water-holding capacity (Evdokimov et al., 2015; Sfakianakis et al., 2015). This explanation may be supported by our findings of $\mathrm{pH}$ in RW, CW, and BUW.

The melting behavior of ice creams is highly variable in the literature depending on their composition and processing conditions. Moriano and Alamprese (2017) observed a time of $18 \mathrm{~min}$ for beginning the melting of their milk-based ice cream, whereas Choi and Shin (2014) reported $50 \mathrm{~min}$ for beginning the melting in commercial vanilla premium ice cream. Regarding studies about replacement of milk by dairy wheys, Rodrigues et al. (2006) found no difference in the beginning of melting time between ice creams with milk replaced 50 and $100 \%$ by whey protein-based products (Dairy Pro) and control ice creams (without whey protein-based products), corroborating with results of this study. 
Table 4. Melting behavior, lightness $\left(L^{*}\right)$, redness $\left(a^{*}\right)$, yellowness $\left(b^{*}\right)$, and instrumental hardness of cream ice cream formulations made with whole milk (WM) and ricotta whey $(\mathrm{RW})$, cheese whey $(\mathrm{CW})$, and butter whey (BUW) at different ratios ${ }^{1}$

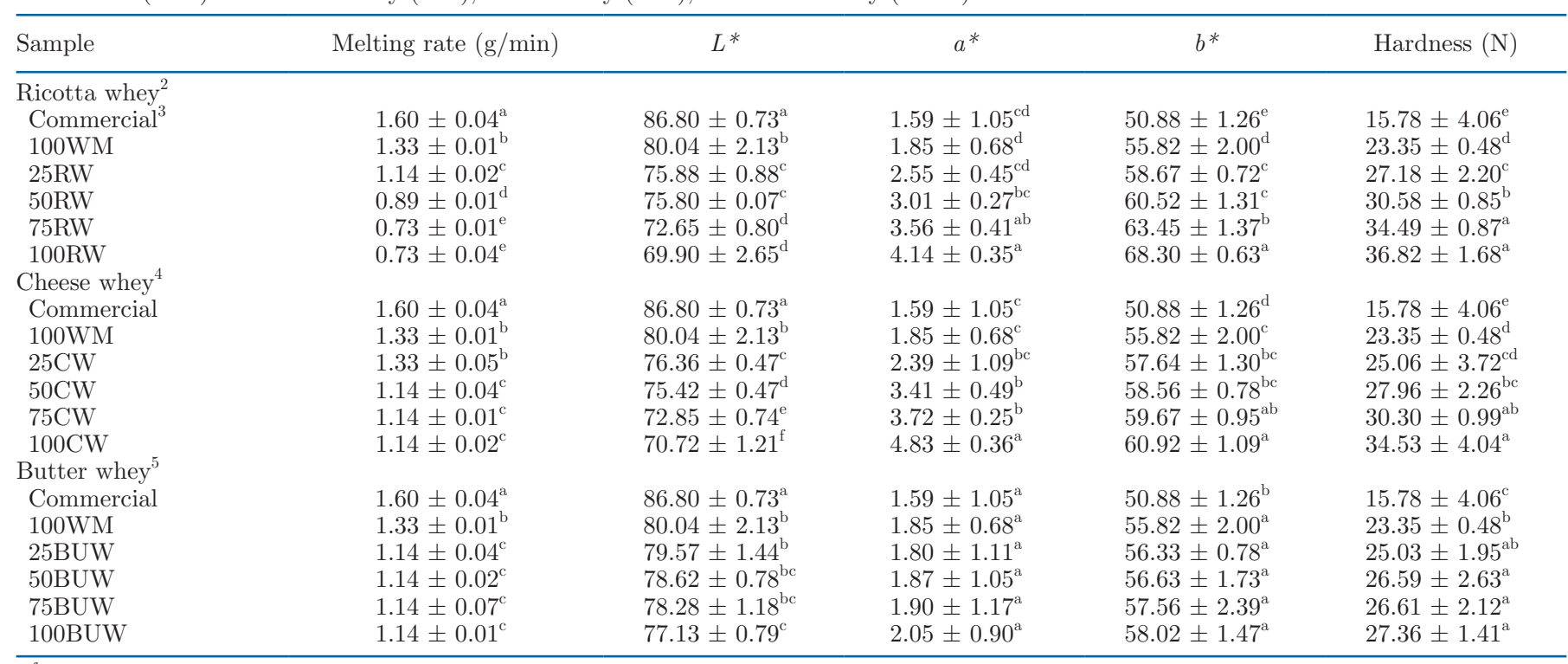

${ }^{\mathrm{a}-\mathrm{f}}$ Means with different letters in the same column (by whey type) represent statistical difference between the cream ice cream formulations using the Tukey test $(P<0.05)$.

${ }^{1}$ Results are expressed as mean $\pm \mathrm{SD}(\mathrm{n}=3$ by each whey type).

${ }^{2} 100 \mathrm{WM}, 25 \mathrm{RW}, 50 \mathrm{RW}, 75 \mathrm{RW}$, and 100RW means cream ice creams with 0, 25, 50, 75, and 100\% ricotta whey, respectively.

${ }^{3}$ Kibon (Rio de Janeiro, Brazil).

${ }^{4} 100 \mathrm{WM}, 25 \mathrm{CW}, 50 \mathrm{CW}, 75 \mathrm{CW}$, and $100 \mathrm{CW}$ means cream ice creams with $0,25,50,75$, and $100 \%$ cheese whey, respectively.

${ }^{5} 100 \mathrm{WM}, 25 \mathrm{BUW}, 50 \mathrm{BUW}, 75 \mathrm{BUW}$, and 100BUW means cream ice creams with $0,25,50,75$, and $100 \%$ butter whey, respectively.

In relation to melting rate, 0.52 to $1.13 \mathrm{~g} / \mathrm{min}$ and $2.75 \mathrm{~g} / \mathrm{min}$ were observed for milk-based ice cream (Moriano and Alamprese, 2017) and commercial ice creams (Lu et al., 2002), respectively. In agreement with findings of the present study, Pereira et al. (2011) also observed that melting rate was decreased by the addition of soy extract (10-30\%) to replace skim milk powder in ice creams. On the other hand, Prindiville et al. (2000) reported an increase in the melting rate due to milk replacement by $100 \%$ of whey protein-based products such as Simplesse $(1.40 \mathrm{~g} / \mathrm{min})$ and Dairy Pro $(1.50 \mathrm{~g} / \mathrm{min})$ compared with ice creams without whey protein-based products $(1.10 \mathrm{~g} / \mathrm{min})$.

\section{Desorption Index}

Desorption is a relevant quality parameter for ice creams, wherein the absence of phase separation during and after melting indicates a good ice cream (Bodyfelt et al., 1988). In our study, any ice cream formulations presented syneresis and, therefore, it was not possible to quantify the whey fraction.

According to Bodyfelt et al. (1988), proteins strongly influence the phase separation after melting, where ice creams containing high protein concentration in water are generally less stable than ice creams with low protein. The ratios between moisture and protein of the evaluated ice creams in this study were not enough to promote phase separation. Nevertheless, our results indicate that the dairy by-products showed potential characteristics for production of ice creams more stable to desorption due to dilution of the protein content from decreasing of the protein content and increasing of the moisture by RW and CW or from increasing of the moisture content by BUW. Syed et al. (2018) observed no effect on syneresis due to replacement of dry milk to dry whey protein $(20,60,80$, and $90 \%)$ in nonfat ice cream.

\section{Instrumental Color}

Commercial samples had similar $a^{*}$ values, higher $L^{*}$ values, and lower $b^{*}$ values $(P<0.05)$ than $100 \% \mathrm{WM}$. Overall, milk replacement by RW and CW decreased $(P<0.05) L^{*}$ values, whereas it increased $(P<0.05)$ $a^{*}$ and $b^{*}$ values (Table 4 ).

For RW ice creams, 75 and $100 \%$ RW had the lowest $L^{*}$ values followed by 50 and $25 \%$ RW $(P<0.05)$, which presented similar $L^{*}$ values. The $25 \%$ RW demonstrated similar $a^{*}$ values to $100 \% \mathrm{WM}$ and $50 \% \mathrm{RW}$; however, it was lower $(P<0.05)$ than 75 and $100 \%$ RW. For $b^{*}$ values, a gradual increase $(P<0.05)$ by 
increasing of RW level was observed; however, no difference was found between 25 and $50 \%$ RW.

With regards to $\mathrm{CW}, L^{*}$ decreased $(P<0.05)$ as $\mathrm{CW}$ levels increased. The $100 \mathrm{CW}$ showed the highest $(P<$ $0.05) a^{*}$ values, and 50 and $75 \% \mathrm{CW}$ had higher $(P$ $<0.05) a^{*}$ values than $100 \%$ WM. No difference was observed among 25, 50, and $75 \% \mathrm{CW}$, or between $100 \%$ $\mathrm{WM}$ and $25 \% \mathrm{CW}$. The 100 and $75 \% \mathrm{CW}$ exhibited higher $(P<0.05) b^{*}$ values than $100 \% \mathrm{WM}$; however, similar values for this parameter were found between 25 , 50, and $75 \% \mathrm{CW}$, and between $100 \% \mathrm{WM}, 25 \%$ $\mathrm{CW}$, and $50 \% \mathrm{CW}$.

The addition of BUW led to slight decrease $(P<$ $0.05)$ of $L^{*}$ values, wherein 100BW showed lower $(P$ $<0.05) L^{*}$ values than $100 \% \mathrm{WM}$ and $25 \% \mathrm{BUW}$. No change was observed in $a^{*}$ and $b^{*}$ values among BUW ice creams and $100 \%$ WM.

Color is directly linked to the appearance of dairy products, and it is one of the most important quality attributes that influences the consumer's acceptability. The white color of milk results of the presence of colloidal particles such as milk fat globules and casein micelles, capable of scattering light in the visible spectrum (Walstra et al., 2006). Our results may be explained by color of evaluated wheys in relation to WM. Ricotta whey, CW and BUW have lower $L^{*}$ values than WM, whereas RW and CW have lower $a^{*}$ and $b^{*}$ values, and BUW has similar $a^{*}$ and $b^{*}$ values compared with WM (Meneses et al., 2020). The pale whey color could decrease the brightness and increase $a^{*}$ and $b^{*}$ coordinates. Moreover, according to Roland et al. (1999), $L^{*}$ values and lipid content have a positive correlation in ice creams. Dairy wheys have reduced lipid and casein contents compared with WM (Morin et al., 2006; Bald et al., 2014; Cortellino and Rizzolo, 2018). However, considering the obtaining process of the evaluated dairy wheys, BUW is the closest to milk in relation lipid and casein contents (Morin et al., 2006), which corroborates with our data of proximate composition and explains the minor color changes by BUW addition.

No studies have evaluated instrumental color of ice creams with different levels of RW, CW, and BUW and, therefore, our findings were also compared with other dairy products. Delikanli and Ozcan (2014) also reported a decreasing in $L^{*}$, and an increasing in $a^{*}$ and $b^{*}$ values after addition of $100 \%$ whey proteins in yogurt.

\section{Instrumental Hardness}

Commercial samples had the lowest $(P<0.05)$ hardness. Regarding RW, hardness gradually increased $(P$ $<0.05)$ due to increase of RW levels, however similar hardness was observed between 100 and $75 \%$ RW. For
CW, 50, 75, and 100\% CW showed higher $(P<0.05)$ hardness compared with $100 \% \mathrm{WM}$, and no difference was found for this parameter between 100\% WM and $25 \% \mathrm{CW}$, between 25 and $50 \% \mathrm{CW}$, between 50 and $75 \% \mathrm{CW}$, or between 75 and $100 \% \mathrm{CW}$. With regards to BUW, 100\% WM had lower $(P<0.05)$ hardness than 50,75 , and $100 \%$ BUW, and no difference was observed for this parameter between 100\% WM and 25\% BUW, or among all ice creams with BUW. Akbari et al. (2016) reported a negative correlation between instrumental hardness and lipid content. According to Guinard et al. (1997), the reduction in the lipid content stimulates the formation of ice crystals resulting in a harder ice cream. In our study, the effect of BUW in hardness was less pronounced when compared with other dairy wheys (RW and CW), which may be explained by lower lipid reduction resulting from the addition of BUW. This fact may be reinforced by total lipid content of RW $(0.02 \%), \mathrm{CW}(0.28 \%)$, and BUW $(0.58 \%)$ in relation to WM (3.15\%; Meneses et al., 2020).

A similar pattern for hardness was observed in lowfat ice cream (Akbari et al., 2016), in yogurt milk added of $100 \%$ of whey proteins (Delikanli and Ozcan, 2014), and in flan-type dairy dessert supplemented with $4.5 \%$ of whey protein concentrate (Frederico et al., 2016).

Although texture of ice cream varies according to ingredients and processing conditions, hardness values ranging from $12.60 \mathrm{~N}$ to $38.61 \mathrm{~N}$ represent high-quality ice creams that are considered acceptable by consumers (Lu et al., 2002; WHO, 2003). In our study, RW, CW, and BUW from 25 to $100 \%$ showed hardness between 27.18 and $36.82,25.06$ and 34.52 , and 25.03 and 27.36 $\mathrm{N}$, respectively, which indicates the potential of these dairy wheys for production of ice cream with adequate texture.

\section{Sensory Analysis}

Consumer Acceptance. The 100\% WM received lower scores $(P<0.05)$ for appearance, aroma, texture and overall liking than commercial, 25, 50, 75, and $100 \%$ RW samples, which demonstrated similar scores for these attributes (Table 5). Likewise, it was observed for aroma, texture, and overall liking for use of CW. For flavor, 50, 75, and 100\% RW had higher scores $(P$ $<0.05)$ than $100 \% \mathrm{WM}$ and the commercial sample, $100 \%$ WM exhibited the lowest score $(P<0.05)$, and no difference was found between $25 \%$ RW and the commercial ice cream. The $100 \% \mathrm{WM}$ scored lower $(P$ $<0.05)$ for flavor compared with the other $\mathrm{CW}$ ice cream formulations; however, similar flavor scores were observed for $100 \% \mathrm{WM}$ and $100 \% \mathrm{CW}$ in relation to commercial sample. Additionally, 25, 50, and $75 \% \mathrm{CW}$ had higher scores $(P<0.05)$ for flavor than $100 \% \mathrm{WM}$ 
Table 5. Acceptance and purchase intention scores of cream ice cream formulations made with whole milk (WM) and ricotta whey (RW), cheese whey $(\mathrm{CW})$, and butter whey $(\mathrm{BUW})$ at different ratios ${ }^{1}$

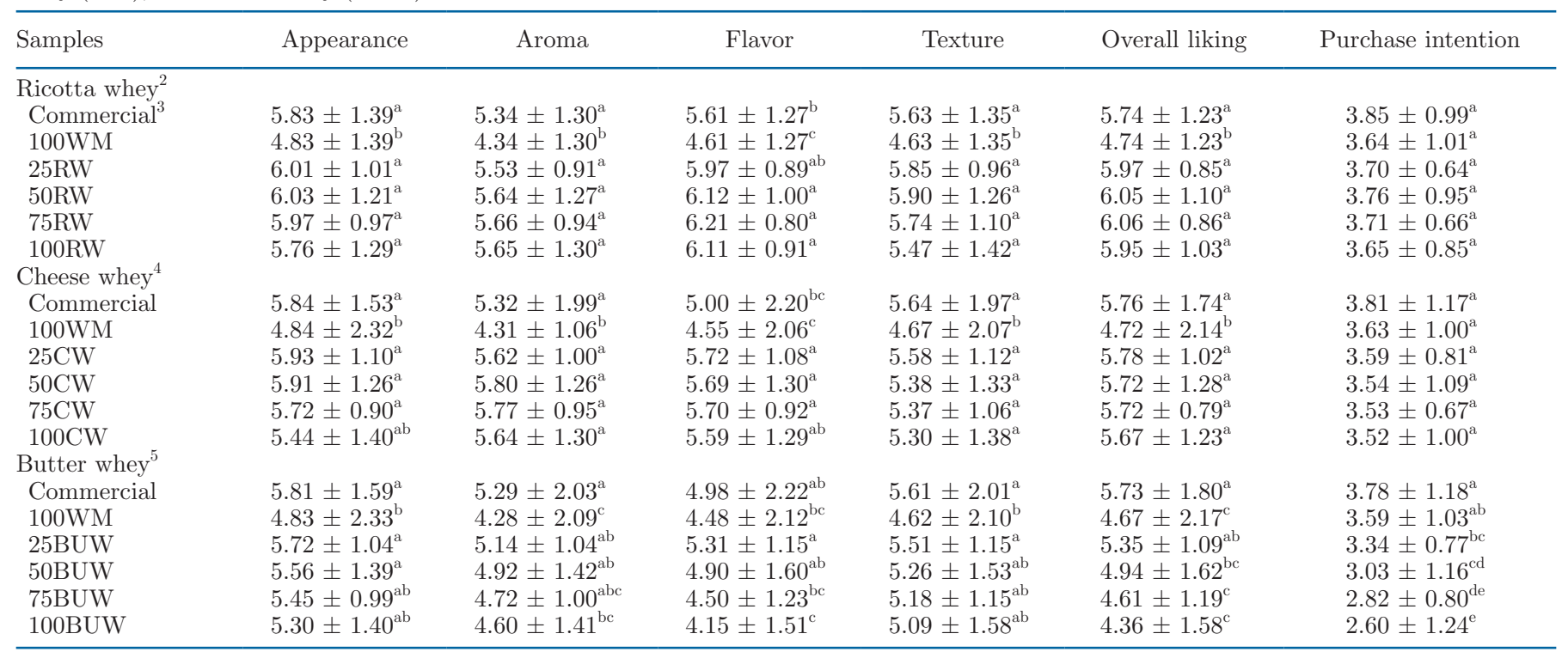

\footnotetext{
${ }^{\mathrm{a}-\mathrm{e}}$ Means with different letters in the same column (by whey type) represent statistical difference between the cream ice cream formulations using the Tukey test $(P<0.05)$.

${ }^{1}$ Results are expressed as mean $\pm \mathrm{SD}(\mathrm{n}=100$ by each whey type); appearance, aroma, flavor, texture, and overall liking were evaluated on a 7 -point category scale $(1=$ dislike very much to $7=$ like very much $)$; purchase intention was evaluated on a 5 -point category scale $(1=$ certainly would not buy to $5=$ certainly would buy).

${ }^{2} 100 \mathrm{WM}, 25 \mathrm{RW}, 50 \mathrm{RW}, 75 \mathrm{RW}$, and 100RW means cream ice creams with $0,25,50,75$, and $100 \%$ ricotta whey, respectively.

${ }^{3}$ Kibon (Rio de Janeiro, Brazil).

${ }^{4} 100 \mathrm{WM}, 25 \mathrm{CW}, 50 \mathrm{CW}, 75 \mathrm{CW}$, and $100 \mathrm{CW}$ means cream ice creams with $0,25,50,75$, and $100 \%$ cheese whey, respectively.

${ }^{5} 100 \mathrm{WM}, 25 \mathrm{BUW}, 50 \mathrm{BUW}, 75 \mathrm{BUW}$, and 100BUW means cream ice creams with 0, 25, 50, 75, and $100 \%$ butter whey, respectively.
}

and commercial ice cream. With regards to appearance of $\mathrm{CW}$ ice creams, 25,50 , and $75 \% \mathrm{CW}$ and the commercial sample had similar scores $(P<0.05)$, which were higher than $100 \%$ WM. No difference $(P<0.05)$ was observed between $100 \% \mathrm{CW}$ and the other $\mathrm{CW}$ ice cream formulations, or between 100\% WM and 100\% CW. Moreover, purchase intention was not affected by addition of either RW or CW.

In relation to BUW, commercial sample, 25 and $50 \%$ BUW received higher scores $(P<0.05)$ for appearance than $100 \% \mathrm{WM}$, however, no difference in the appearance was found between all BUW ice cream formulations. The lowest aroma score $(P<0.05)$ was for $100 \%$ WM, which showed difference $(P<0.05)$ only for $25 \%$ BUW, $50 \%$ BUW and the commercial sample. Moreover, 25, 50, and $75 \%$ BUW and commercial ice cream demonstrated similar aroma score. The $25 \%$ BUW had higher flavor $(P<0.05)$ than $100 \% \mathrm{WM}$, and demonstrated similar flavor scores to commercial ice cream and $50 \%$ BUW. On the other hand, 100\% BUW showed lower flavor $(P<0.05)$ than commercial ice cream, and was similar to $100 \% \mathrm{WM}$ and $75 \%$ BUW. For texture, commercial sample and 25\% BUW received higher scores $(P<0.05)$ than $100 \% \mathrm{WM}$, and no difference was found between all BUW ice cream formulations.
For overall liking commercial sample showed higher score $(P<0.05)$ than other ice cream formulations, except $25 \%$ BUW, which received similar overall liking to commercial sample. Commercial sample and $100 \%$ WM had higher purchase intention $(P<0.05)$ than 50, 75, and 100\% BUW; however, $100 \% \mathrm{WM}$ and $25 \%$ BUW showed similar purchase intention.

There are lack of sensorial studies evaluating acceptance and purchase intention of ice creams with different levels of RW, CW, and BUW. The main limitation of the use of wheys in dairy products has been related to adverse sensory effects, which strongly depend on whey type, ingredient ratios including whey concentration, type of dairy product and their processing parameters (Morin et al., 2006; Bald et al., 2014; Cortellino and Rizzolo, 2018). Therefore, the results from literature are highly variable. Prindiville et al. (2000) concluded that the milk replacement by addition of $100 \%$ of whey protein-based (Simplesse) did not influence flavor; however, it decreased creaminess and hardness of the ice cream. Sakhale et al. (2012), evaluating mango dairy beverages developed with different cheese whey levels ranging from $70 \%$ to $80 \%$, showed flavor and overall liking decreased due to increasing of the whey levels. Additionally, Castro et al. (2013) reported no effect in 
Table 6. Just-about-right (JAR) scores of cream ice cream formulations made with whole milk (WM) and ricotta whey (RW), cheese whey $(\mathrm{CW})$, and butter whey (BUW) at different ratios ${ }^{1}$

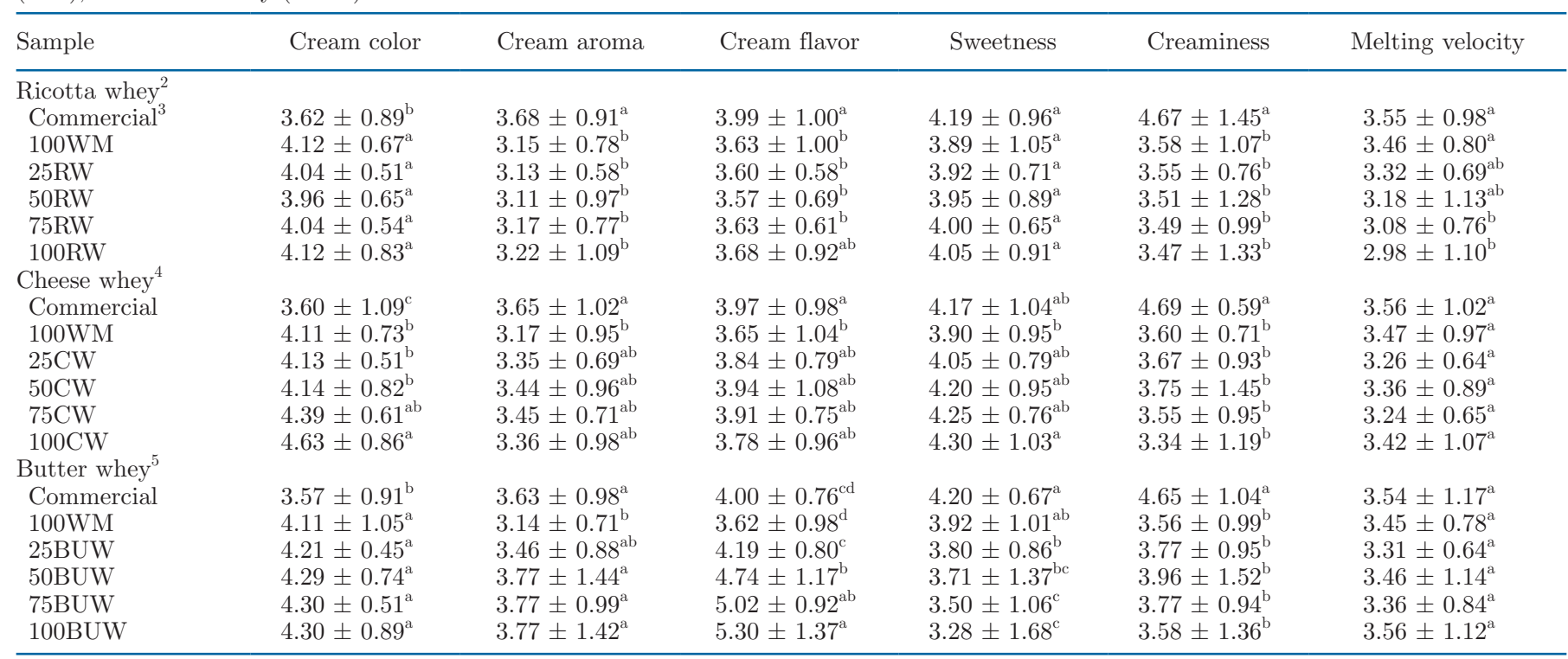

\footnotetext{
${ }^{\mathrm{a}-\mathrm{d}}$ Means with different letters in the same column (by whey type) represent statistical difference between the cream ice cream formulations using the Tukey test $(P<0.05)$.

${ }^{1}$ Results are expressed as mean $\pm \mathrm{SD}(\mathrm{n}=100$ by each whey type); categories were evaluated on a 7 -point category scale $(1=$ extremely little to $7=$ extremely much).

${ }^{2} 100 \mathrm{WM}, 25 \mathrm{RW}, 50 \mathrm{RW}, 75 \mathrm{RW}$, and 100RW means cream ice creams with 0, 25, 50, 75, and 100\% ricotta whey, respectively.

${ }^{3}$ Kibon (Rio de Janeiro, Brazil).

${ }^{4} 100 \mathrm{WM}, 25 \mathrm{CW}, 50 \mathrm{CW}, 75 \mathrm{CW}$, and $100 \mathrm{CW}$ means cream ice creams with $0,25,50,75$, and $100 \%$ cheese whey, respectively.

${ }^{5} 100 \mathrm{WM}, 25 \mathrm{BUW}, 50 \mathrm{BUW}, 75 \mathrm{BUW}$, and 100BUW means cream ice creams with 0, 25, 50, 75, and 100\% butter whey, respectively.
}

overall liking of strawberry probiotic dairy drinks with added $35 \%$ of cheese whey, whereas levels equal to or above $50 \%$ decreased the overall liking.

$J A R$ Scores. Just-about-right scores of the ice cream formulations are shown in Table 6. For RW ice creams, no difference was observed in cream color, cream aroma, cream flavor, sweetness, or creaminess between 100\% WM and ice creams with added RW. However, 75 and $100 \%$ RW were perceived below ideal $(P<0.05)$ for melting velocity compared with $100 \%$ WM, corroborating with our results of melting rate.

Considering CW ice creams, $100 \% \mathrm{CW}$ was above ideal $(P<0.05)$ for cream color and sweetness compared with $100 \%$ WM, whereas similar JAR scores were found for cream aroma, cream flavor, creaminess, and melting velocity between $100 \% \mathrm{WM}$ and all CW ice creams.

The ice creams with added BUW had higher $(P<$ $0.05)$ cream aroma and cream flavor than $100 \%$ WM; however, it demonstrated similar JAR scores to the commercial sample in relation to cream aroma. Among BUW ice creams, only $25 \%$ BUW was similar in cream flavor to the commercial sample. Moreover, 75 and $100 \%$ BUW were below ideal $(P<0.05)$ for sweetness compared with $25 \%$ BUW and 100\% WM, which had similar JAR scores for this parameter. No difference was observed in JAR scores for cream color, creaminess, and melting velocity between $100 \% \mathrm{WM}$ and ice creams with added BUW.

The $100 \%$ WM was rated as having higher $(P<0.05)$ cream color and lower $(P<0.05)$ cream aroma, cream flavor, sweetness, and creaminess than the commercial sample, JAR scores were similar for melting velocity in both samples.

It is worth highlighting that there are no studies in the literature about JAR attributes of ice creams made with RW, CW, and BUW substitutions for milk. Furthermore, each level and type of dairy by-product will determine different effects on the final product due mainly to specific interactions with the other food ingredients (Morin et al., 2006; Bald et al., 2014; Cortellino and Rizzolo, 2018). Nevertheless, previous studies already reported a decrease in the melting velocity of ice cream with the addition of $4 \%$ whey protein isolate in substitution for skim milk (El-Zeini et al., 2016), an increase of chocolate flavor perception in dairy beverage due to the addition of 15 and $45 \%$ cheese whey (da Silveira et al., 2015), as well as an increase of percep- 
tion of sweetness and orange flavor athletic drink with the addition of $66.67 \%$ cottage cheese whey (Crippen and Jeon, 1984).

Principal Component Analysis and Partial Least Squares Regression. Principal component analysis explained $91.59 \%$ of the total data variance for RW ice creams (Figure 1A). The 2 principal components (PC1 and $\mathrm{PC} 2$ ) divided the ice cream formulations in 3 groups (commercial sample; $100 \% \mathrm{WM}$ and $25 \% \mathrm{RW}$; and 50, 75, and $100 \% \mathrm{RW}$ ). The formulations 50, 75, and $100 \%$ RW ice creams were characterized by appearance, texture, aroma, flavor, moisture, TA, hardness, and $a^{*}$ and $b^{*}$ values. The $100 \% \mathrm{WM}$ and $25 \% \mathrm{RW}$ ice creams were grouped by cream color, $\mathrm{pH}$, energy value, content of proteins, ashes, and carbohydrates. The commercial sample was identified by cream aroma, cream flavor, creaminess, sweetness, melting velocity, melting rate, $L^{*}$ values, lipid content, and purchase intention. Regarding PLSR for ice creams developed with RW, it explained $96.10 \%$ of consumer overall liking (y-axis) and $91.00 \%$ of the physicochemical and sensory scores (x-axis), yielding an accumulated $\mathrm{Q}^{2}$ of 0.842. Moisture, appearance, aroma, flavor, and texture contributed positively to overall liking, whereas ash, carbohydrates, and energy value were detrimental to overall liking (Figure 1A). Among these attributes, high levels of RW (75 and 100\%) increased the hardness, possibly leading to lower perception of melting velocity and creaminess, which could be a limiting factor to use of this dairy whey depending on ice cream formulation. The increased hardness in ice cream by addition of high levels of RW (75 and 100\%) may be attributed to low lipid content in RW $(0.02 \%)$ compared with WM (3.15\%; Meneses et al., 2020), which stimulates the formation of ice crystals resulting in a harder ice cream (Guinard et al., 1997) with lower creaminess and melting velocity. Akalin et al. (2008) reported that the addition of $4 \%$ whey protein isolate increased the hardness of low-fat ice creams. El-Zeini et al. (2016) observed a decrease in the melting velocity in ice cream due to the substitution of skim milk powder with whey protein isolate powder at $4 \%$. Nevertheless, in our study, RW ice creams had similar overall liking to the commercial sample and higher $(P<0.05)$ scores for this parameter compared with 100\% WM.

For CW ice creams (Figure 1B), PCA explained $85.25 \%$ of the total variance of the data. Principal component 1 and $\mathrm{PC} 2$ divided the ice cream formulations in 4 groups (commercial sample and 25\% CW; $100 \% \mathrm{WM} ; 50$ and $75 \% \mathrm{CW} ; 100 \% \mathrm{CW})$. The $100 \%$ CW was identified by hardness, cream color, $a^{*}$ and $b^{*}$ values. The 50 and $75 \% \mathrm{CW}$ were grouped by moisture, flavor, cream flavor, sweetness, aroma, appearance, and texture. Commercial sample and 25\% RW were characterized by melting velocity, melting rate, $\mathrm{pH}$, lipid content, $L^{*}$ values, cream aroma, creaminess, and purchase intention. The $100 \% \mathrm{WM}$ was identified by TA, energy value, and content of ashes, proteins, and carbohydrates. In relation to PLSR for CW ice creams, it explained $96.00 \%$ of consumer overall liking (y-axis) and $84.80 \%$ of the physicochemical and sensory scores (x-axis), yielding an accumulated $\mathrm{Q}^{2}$ of 0.878 . Moisture, appearance, aroma, flavor, texture, cream aroma, cream flavor, and sweetness were determinants to increase the overall liking. On the other hand, carbohydrates and TA contributed negatively to overall liking of the ice cream formulations (Figure 1B). All CW ice cream formulations, $100 \% \mathrm{WM}$ and commercial sample had similar TA. This fact can be explained by the fact that CW and WM has similar TA $(0.21$ and 0.19 , respectively) (Meneses et al., 2020). In relation to flavor, consumers perceived $100 \% \mathrm{CW}$ as sweeter compared with 100\% WM; however, this attribute was similar among $\mathrm{CW}$ ice cream formulations and commercial sample. The changes in flavor may be associated with higher moisture content in CW (93.53\%) compared with milk $(84.80 \%)$ (Meneses et al., 2020), resulting in a more solubilization of the ice cream ingredients, and consequently increasing the perception of flavor and sweetness. Similarly, da Silveira et al. (2015) reported that the addition of 15 and $45 \%$ of $\mathrm{CW}$ increased the flavor perception of chocolate dairy beverage. Moreover, cream flavor and cream aroma was not influence by addition of $\mathrm{CW}$ in comparison with $100 \% \mathrm{WM}$ and commercial sample. Regarding overall liking, the scores for $\mathrm{CW}$ ice creams and the commercial sample were similar and were higher $(P<0.05)$ than those for $100 \%$ WM. These findings indicate the potential of $\mathrm{CW}$ for use in cream ice cream formulations by dairy industries.

Regarding BUW ice creams, PCA explained 85.13\% of the total data variance (Figure 1C). The PC1 and PC2 divided the ice cream formulations into 3 groups (commercial sample; $100 \% \mathrm{WM}$ and $25 \%$ BUW; and 50, 75 , and $100 \%$ BUW). The group with 50, 75, and $100 \%$ BUW was identified by cream flavor, cream aroma, TA, and moisture; whereas $100 \% \mathrm{WM}$ and $25 \%$ BUW were identified by flavor, sweetness, purchase intention, $\mathrm{pH}$, and energy value. The commercial sample was grouped by creaminess, aroma, texture, appearance, $L^{*}$ values, and melting rate. With regards to PLSR model for ice creams with BUW, it explained $98.90 \%$ of consumer overall liking (y-axis) and $80.90 \%$ of the physicochemical and sensory scores (x-axis), yielding an accumulated $\mathrm{Q}^{2}$ of 0.810 . Lipid content, energy value, $\mathrm{pH}$, melting rate, $L^{*}$, and sweetness contributed positively to overall liking; however, TA, $a^{*}, b^{*}$, hardness, cream color, and 
(A)

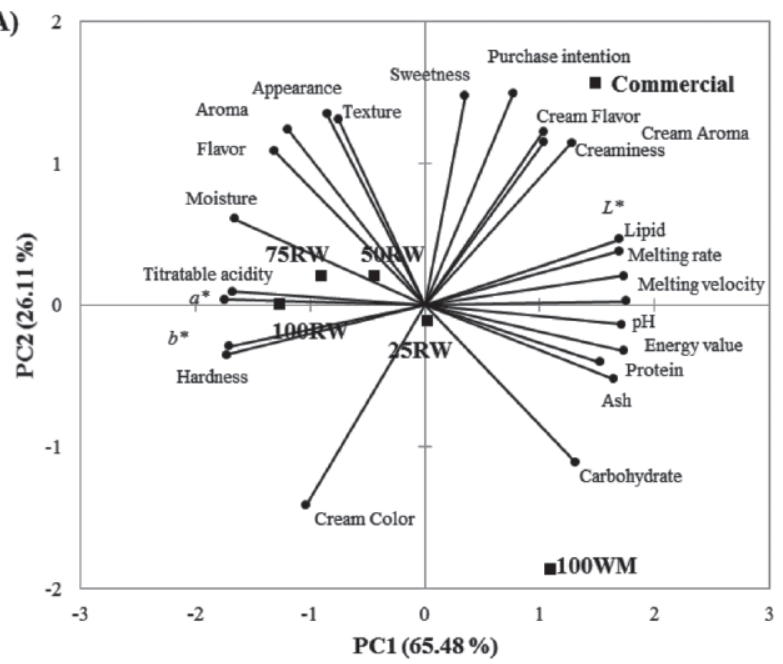

(B)

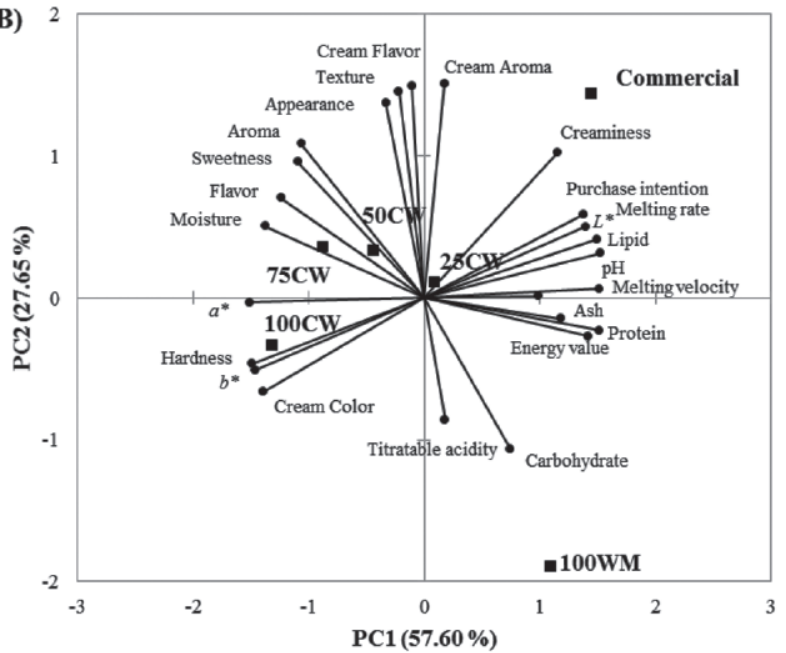

(C)

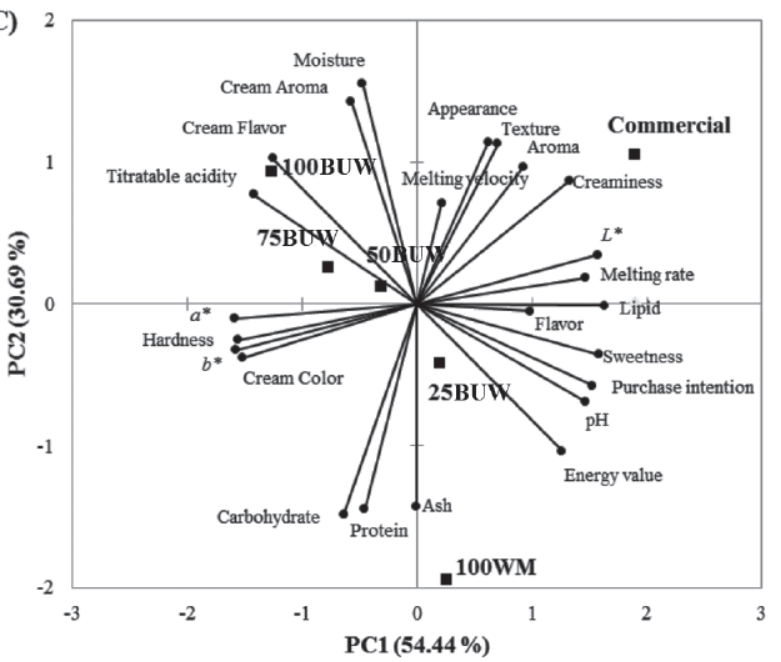

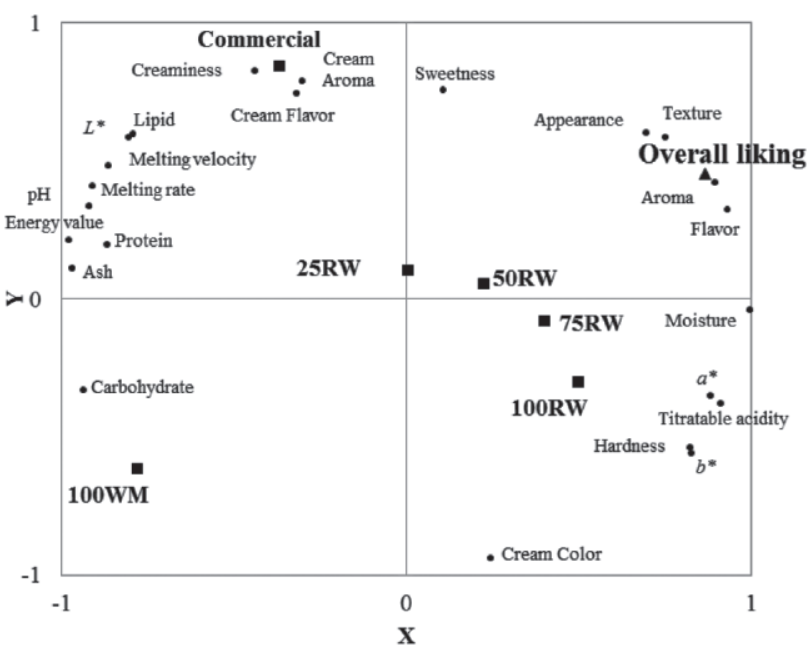
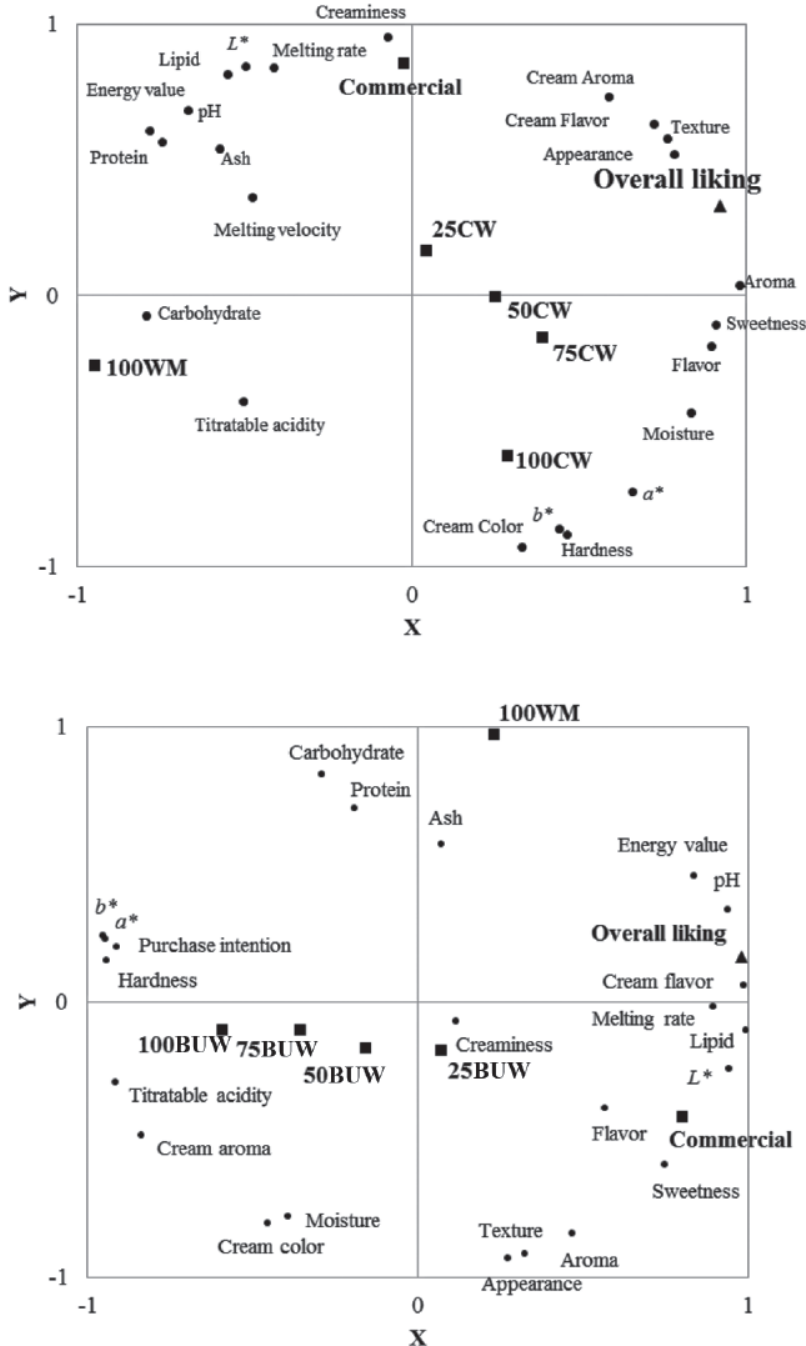

Figure 1. Sensory data of cream ice creams made with (A) ricotta whey, (B) cheese whey, and (C) butter whey in the plane defined by 2 principal components ( $\mathrm{PC} 1$ and $\mathrm{PC} 2$, left) and partial least squares regression model where $\mathrm{x}$-axis $=$ sensory attributes and $\mathrm{y}$-axis $=$ consumer acceptance (right). 100WM, 25(RW, CW, and BUW), 50(RW, CW, and BUW), 75(RW, CW, and BUW), and 100(RW, CW, and BUW) indicate chocolate ice creams with $0\left(100 \%\right.$ whole milk), $25,50,75$, and $100 \%$ ricotta whey, cheese whey, and butter whey, respectively. $L^{*}=$ lightness, $a^{*}=$ redness, and $b^{*}=$ yellowness. 
cream flavor were detrimental to overall liking (Figure 1C). The addition of BUW from 50 to $100 \%$ increased the hardness and TA, which may have led to a decrease in creaminess and to an increase in the perception of cream flavor and consequently, a lower overall liking. The increase of hardness in ice cream due to addition of high levels of BUW (50, 75, and 100\%) may be attributed to BUW $(0.58 \%)$ having a lower lipid content than WM (3.15\%), which accelerate the formation of ice crystals (Guinard et al., 1997; Meneses et al., 2020). Likewise, the increase of TA in ice cream by the addition of BUW from 50 to $100 \%$ may be due to higher TA in BUW $(0.39 \%)$ compared with WM $(0.19 \%$; Meneses et al., 2020). The increase in the perception of cream flavor by addition of high levels of BUW (50, 75, and $100 \%$ ) can be explained by higher moisture content in BUW $(91.36 \%)$ than WM $(84.80 \%)$ leading to a better solubilization of the formulation ingredients and subsequent increased perception of cream flavor. Janiaski et al. (2016) evaluated 4 strawberry-flavored yogurts sold in Brazilian market and concluded that yogurts containing whey protein concentrate had higher consumer perception for artificial strawberry flavor when compared with yogurts without whey protein concentrate.

Considering data from PCA, PLSR, hedonic, and JAR scores, texture and flavor properties are driving factors for the use of RW, CW, and BUW in ice creams depending on level and type of each dairy by-product, which determine the specific interactions with the other food ingredients (Morin et al., 2006; Bald et al., 2014; Cortellino and Rizzolo, 2018).

\section{CONCLUSIONS}

The addition of RW, CW, and BUW reduced the nutritional composition, melting rate, and lightness and increased acidity, redness, yellowness, and hardness of ice creams. There were no changes in $a^{*}$ and $b^{*}$ values, and changes in lipid and hardness were less pronounced when adding BUW. Considering the sensory proprieties, RW and CW at all ratios demonstrated a great potential for use in ice creams without compromising overall liking; however, RW at 75 and $100 \%$ lowered the melting velocity and creaminess, which represents a limiting factor for their use. On the other hand, the use of BUW, especially from 50 to $100 \%$, led to a negative effect on hardness, acidity, creaminess, and cream flavor, which had an important role in decreasing overall liking. Therefore, the dairy by-products evaluated in this study, mainly RW and CW, can be used as milk replacers in cream ice creams for the sustainable and health markets.

\section{ACKNOWLEDGMENTS}

The authors are grateful for the financial support provided by the Fundação Carlos Chagas Filho de Amparo à Pesquisa do Estado do Rio de Janeiro (FAPERJ, RJ, Brazil), grant number E-26/010.001911/2015, and the Conselho Nacional de Desenvolvimento Científico e Tecnológico (CNPq, Brazil), grant number 311422/2016-0. The authors have not stated any conflicts of interest.

\section{REFERENCES}

Agrawal, A. K. 2016. Effect of variation of ginger juice on some physical and sensory properties of ice cream. Indian J. Dairy Sci. 69:1723.

Akalın, A. S., C. Karagözlü, and G. Ünal. 2008. Rheological properties of reduced-fat and low-fat ice cream containing whey protein isolate and inulin. Eur. Food Res. Technol. 227:889-895. https:// doi.org/10.1007/s00217-007-0800-z.

Akbari, M., M. H. Eskandari, M. Niakosari, and A. Bedeltavana. 2016. The effect of inulin on the physicochemical properties and sensory attributes of low-fat ice cream. Int. Dairy J. 57:52-55. https://doi .org/10.1016/j.idairyj.2016.02.040.

AMSA (American Meat Science Association). 2012. Meat Color Measurement Guidelines. 2nd ed. AMSA, Champaign, IL.

ANVISA (Agência Nacional de Vigilância Sanitária). 2001. Resolução n⿳0 12 de 02 de janeiro de 2001. Regulamento Técnico sobre os Padrões Microbiológicos para Alimentos, ANVISA, Brasília, Brasil.

AOAC International. 2012. Official Methods of Analysis. 19th ed. AOAC International, Gaithersburg, MD.

APHA (American Public Health Association). 2001. Compendium of Methods for the Microbiological Examination of Foods. 4th ed. APHA, Washington, DC.

Bald, J. A., A. Vincenzi, A. Gennari, D. N. Lehn, and C. F. V. Souza. 2014. Características físico-químicas de soros de queijo e ricota produzidos no vale do Taquari. Rev. Jovens Pesq. 4:90-99. https:/ /doi.org/10.17058/rjp.v4i3.4602.

Bligh, E. G., and W. J. Dyer. 1959. A rapid method of total lipid extraction and purification. Can. J. Biochem. Physiol. 37:911-917. https://doi.org/10.1139/o59-099.

Bodyfelt, F. W., J. Tobias, and G. M. Trout. 1988. The Sensory Evaluation of Dairy Products. Van Nostrand Reinhold, New York, NY.

Carli, E. M., A. Tirloni, and G. M. Pietta. 2015. Elaboração de bebida láctea acidificada. Rev. CSBEA 1:1-7.

Castro, W. F., A. G. Cruz, M. S. Bisinotto, L. M. R. Guerreiro, J. A. F. Faria, H. M. A. Bolini, R. L. Cunha, and R. Deliza. 2013. Development of probiotic dairy beverages: Rheological properties and application of mathematical models in sensory evaluation. J. Dairy Sci. 96:16-25. https://doi.org/10.3168/jds.2012-5590.

Cheng, J., Y. Ma, X. Li, T. Yan, and J. Cui. 2015. Effects of milk protein-polysaccharide interactions on the stability of ice cream mix model systems. Food Hydrocoll. 45:327-336. https://doi.org/ 10.1016/j.foodhyd.2014.11.027.

Choi, M.-J., and K.-S. Shin. 2014. Studies on physical and sensory properties of premium vanilla ice cream distributed in Korean market. Korean J Food Sci. Anim. Resour. 34:757-762. https:// doi.org/10.5851/kosfa.2014.34.6.757.

Cortellino, G., and A. Rizzolo. 2018. Storage stability of novel functional drinks based on ricotta cheese whey and fruit juices. Beverages 4:67. https://doi.org/10.3390/beverages4030067.

Crippen, K. L., and I. J. Jeon. 1984. Direct-acid-set cottage cheese whey as a base for a shelf-stable athletic-type drink. J. Food Prot. 47:53-57. https://doi.org/10.4315/0362-028X-47.1.53.

Delikanli, B., and T. Ozcan. 2014. Effects of various whey proteins on the physicochemical and textural properties of set type nonfat yoghurt. Int. J. Dairy Technol. 67:495-503. https://doi.org/10.1111/ 1471-0307.12142. 
de Meneses, R. B., L. F. Maciel, M. H. M. de Rocha-Leão, and C. A. Conte-Junior. 2020. Physicochemical characteristics of milk byproducts. Chem. Eng. Trans. 79:37-42.

da Silveira, E. O., J. H. Lopes Neto, L. A. da Silva, A. E. S. Raposo, M. Magnani, and H. R. Cardarelli. 2015. The effects of inulin combined with oligofructose and goat cheese whey on the physicochemical properties and sensory acceptance of a probiotic chocolate goat dairy beverage. Lebensm. Wiss. Technol. 62:445-451. https://doi.org/10.1016/j.lwt.2014.09.056.

El-Nagar, G., G. Clowes, C. M. Tudorica, V. Kuri, and C. S. Brennan. 2002. Rheological quality and stability of yog-ice cream with added inulin. Int. J. Dairy Technol. 55:89-93. https://doi.org/10.1046/j .1471-0307.2002.00042.x.

El-Zeini, H. M., M. M. El-Abd, F. A. Metwaly, M. A. Zeidan, and Y. F. Hassan. 2016. Using whey protein isolate as a substitute of milk solid not fat on chemical and physico-chemical properties of ice cream. J. Food and Dairy Sci. 7:133-137. https://doi.org/10 $.21608 /$ jfds.2016.42822.

Evdokimov, I. A., D. N. Volodin, V. A. Misyura, M. S. Zolotoreva, and M. I. Shramko. 2015. Functional fermented milk desserts based on acid whey. Foods Raw Mater. 3:40-48. https://doi.org/10.12737/ 13116.

FAO (Food and Agriculture Organization of the United Nations). 2013. Milk and Dairy Products in Human Nutrition. FAO, Rome, Italy.

Frederico, C., T. B. Pinto, E. M. Castro, H. H. Suguimoto, E. H. W. Santana, L. C. Aragon-Alegro, and C. H. B. Souza. 2016. Probiotic dairy dessert supplemented with whey protein concentrate: Effect on the viability of Lactobacillus acidophilus, on texture, physicochemical and sensory features. J. Food Nutr. Res. 55:48-56.

Gerhardt, Â., B. W. Monteiro, A. Gennari, D. N. Lehn, and C. F. V. de Souza. 2013. Características físico-químicas e sensoriais de bebidas lácteas fermentadas utilizando soro de ricota e colágeno hidrolisado. JRev. Inst. Laticínios Cândido Tostes 68:41-50. https: //doi.org/10.5935/2238-6416.20130007.

Guinard, J.-X., C. Zoumas-Morse, L. Mori, B. Uatoni, D. Panyam, and A. Kilara. 1997. Sugar and fat effects on sensory properties of ice cream. J. Food Sci. 62:1087-1094. https://doi.org/10.1111/j .1365-2621.1997.tb15044.x

Haque, Z. U., and T. Ji. 2003. Cheddar whey processing and source: II. Effect on non-fat ice cream and yoghurt. Int. J. Food Sci. Technol. 38:463-473. https://doi.org/10.1046/j.1365-2621.2003.00705.x.

Hickey, C. D., M. G. O'Sullivan, J. Davis, D. Scholz, K. N. Kilcawley, M. G. Wilkinson, and J. J. Sheehan. 2018. The effect of buttermilk or buttermilk powder addition on functionality, textural, sensory and volatile characteristics of Cheddar-style cheese. Food Res. Int. 103:468-477. https://doi.org/10.1016/j.foodres.2017.09.081.

Janiaski, D. R., T. C. Pimentel, A. G. Cruz, and S. H. Prudencio. 2016. Strawberry-flavored yogurts and whey beverages: What is the sensory profile of the ideal product? J. Dairy Sci. 99:52735283. https://doi.org/10.3168/jds.2015-10097.

Lu, T.-J., C.-W. Chuang, and Y.-H. Chang. 2002. Sensory and physicochemical analyses on commercial taro ice products. J. Food Drug Anal. 10:55-63.

Mahdian, E., M. M. Tehrani, and M. Nobahari. 2012. Optimizing yoghurt-ice cream mix blend in soy based frozen yoghurt. J. Agric. Sci. Technol. 14:1275-1284.

Moriano, M. E., and C. Alamprese. 2017. Honey, trehalose and erythritol as sucrose-alternative sweeteners for artisanal ice cream. A pilot study. Lebensm. Wiss. Technol. 75:329-334. https://doi.org/ 10.1016/j.lwt.2016.08.057

Morin, P., Y. Pouliot, and R. Jiménez-Flores. 2006. A comparative study of the fractionation of regular buttermilk and whey buttermilk by microfiltration. J. Food Eng. 77:521-528. https://doi.org/ 10.1016/j.jfoodeng.2005.06.065

Oliveira, K. H., J. A. R. Souza, and A. R. Monteiro. 2008 Rheological characterization of ice cream. Food Sci. Technol. (Campinas) 28:592-598. https://doi.org/10.1590/S0101-20612008000300014.

Palazzo, A. B., and H. M. A. Bolini. 2017. Sweeteners in diet chocolate ice cream: Penalty analysis and acceptance evaluation. J. Food Stud. 6:1-13. https://doi.org/10.5296/jfs.v6i1.10655.
Panesar, P. S., and J. F. Kennedy. 2012. Biotechnological approaches for the value addition of whey. Crit. Rev. Biotechnol. 32:327-348. https://doi.org/10.3109/07388551.2011.640624.

Pereira, C., A. Andrejewski, A. Mattana, C. A. P. Schmidt, P. L. M. Barreto, and E. S. Sant Ánna. 2014. Processing and microbiological characterization of diet strawberry ice cream with addition of whey protein concentrate, whole milk powder and sweeteners. Int. J. Nutr. Food Sci. 3:97-103. https://doi.org/10.11648/j.ijnfs .20140302 .22

Pereira, G. G., J. V. de Resende, L. R. de Abreu, T. M. de Oliveira Giarola, and I. T. Perrone. 2011. Influence of the partial substitution of skim milk powder for soy extract on ice cream structure and quality. Eur. Food Res. Technol. 232:1093-1102. https://doi.org/ 10.1007/s00217-011-1483-z.

Prindiville, E. A., R. T. Marshall, and H. Heymann. 2000. Effect of milk fat, cocoa butter, and whey protein fat replacers on the sensory properties of low fat and nonfat chocolate ice cream. J. Dairy Sci. 83:2216-2223. https://doi.org/10.3168/jds.S0022 $-0302(00) 75105-8$.

Rodrigues, A. P., C. V. Fontana, E. Padilha, M. Silvestrin, and M. M. M. Augusto. 2006. Elaboração de sorvete sabor chocolate com teor de gordura reduzido utilizando soro de leite em pó. VETOR $16: 55-62$.

Rodríguez, T., and A. M’Boumba. 2011. Utilización del suero de queso en helado. RVCTA 21:9-12.

Roland, A. M., L. G. Phillips, and K. J. Boor. 1999. Effects of fat replacers on the sensory properties, color, melting, and hardness of ice cream. J. Dairy Sci. 82:2094-2100. https://doi.org/10.3168/jds .S0022-0302(99)75451-2.

Sakhale, B., N. V. Pawar, and R. C. Ranveer. 2012. Studies on the development and storage of whey based RTS beverage from mango cv. Kesar. J. Food Process. Technol. 3:1000148. https://doi.org/10 $.4172 / 2157-7110.1000148$.

Sfakianakis, P., E. Topakas, and C. Tzia. 2015. Comparative study on high-intensity ultrasound and pressure milk homogenization: Effect on the kinetics of yogurt fermentation process. Food Bioprocess Technol. 8:548-557. https://doi.org/10.1007/s11947-014 $-1412-9$.

Stone, H., and J. L. Sidel. 2004. Sensory Evaluation Practices. Academic Press, London, UK

Syed, Q. A., S. Anwar, R. Shukat, and T. Zahoor. 2018. Effects of different ingredients on texture of ice cream. J. Nutr. Health Food Eng. 8:422-435. https://doi.org/10.15406/jnhfe.2018.08.00305.

Tsuchiya, A. C., A. G. M. Silva, D. Brandt, D. L. Kalschne, D. A. Drunkler, and E. Colla. 2017. Lactose-reduced ice cream enriched with whey powder. Semina Ciênc. Agrár. 38:749-758. https://doi .org/10.5433/1679-0359.2017v38n2p749.

Walstra, P., J. T. M. Wouters, and T. J. Geurts. 2006. Dairy Science and Technology. CRC Press, Boca Raton, FL.

WHO (World Health Organization). 1983. Microbiological Criteria for Foods: Summary of Recommendations of FAO/WHO Expert Consultations and Working Groups 1975-1981, WHO, Geneva, Switzerland

WHO (World Health Organization). 2003. Assuring Food Safety and Quality: Guidelines for Strengthening National Food Control Systems.WHO, Geneva, Switzerland.

Wold, S., M. Sjöström, and L. Eriksson. 2001. PLS-regression: A basic tool of chemometrics. Chemom. Intell. Lab. Syst. 58:109-130. https://doi.org/10.1016/S0169-7439(01)00155-1.

\section{ORCIDS}

R. B. Meneses (ํ) https://orcid.org/0000-0003-3241-6396

M. S. Silva (1) https://orcid.org/0000-0003-1678-106X

M. L. G. Monteiro ๑ https://orcid.org/0000-0001-6928-1347

C. A. Conte-Junior @ https://orcid.org/0000-0001-6133-5080 